\title{
Tool for Purchasing Positioning - Assessment of Purchasing Maturity and Performance Level
}

\author{
Jens Andreas Barth ${ }^{1}$ \\ ${ }^{1}$ Management Faculty, Comenius University, Bratislava, Slovakia \\ Correspondence: Jens Andreas Barth, Management Faculty, Comenius University, Bratislava, Slovakia
}

Received: November 12, 2018

Accepted: November 29, 2018

Online Published: December 3, 2018

doi:10.5430/bmr.v7n4p29

URL: https://doi.org/10.5430/bmr.v7n4p29

\begin{abstract}
This article provides a practical approach to evaluate the performance level of a purchasing organization before (ex ante) and after (ex post) the execution of a cost optimization project.

A purchasing organization is often questioned, when performance (output) is not provided at the expected level (for example poor EBIT contribution). Provided there is a connection between performance level and the positioning of a purchasing organization, the interesting questions are: which aspects influence the performance level (output) and subsequently how can the effectiveness (input) of a purchasing organization be measured.

The aim of this paper is to examine an applicable positioning tool, that helps to analyse and assess performance level and supports the selection of appropriate and tangible measures for sustainable cost optimization as an integrated tool of a cost optimization approach in the analysis phase.

The utilized methodology considers an internet and literature research of typical evaluation methods and approaches, authors observation and synthesis of knowledge.

Based on the research and subsequently logical reasoning a positioning tool is derived. Initially two formulated hypotheses are tested and confirmed through the application of the tool in three executed cost optimization projects and finally validated by semi-structured interviews with six purchasing experts.

More accurate and precise evaluation of a purchasing organization prior to execution of a cost optimization project could lead to a better selection of cost optimization approaches and can help to reduce waste of time, capacity and expenditures. Assessment after project closure help to demonstrate the lift in performance.
\end{abstract}

Keywords: effectiveness, efficiency, input factor, positioning, purchasing performance level

JEL Classification: L22, L62

\section{Introduction}

In general, cost optimization projects as well as purchasing organizations are measured against their most important performance indicator, saving. The nature of cost-reduction projects is to reduce costs and to improve the so far provided performance level. Though this measure alone usually keeps the organization very busy, further objectives of business sustainability still exist, like quality, on time delivery and access to innovation.

Besides the above described dilemma, savings on the one side, business sustainability on the other, sometimes projects face contradictory situations: Cost-reduction targets can be achieved easily in one category and are hardly met in another. In such a situation external help of consultancies and experts is often requested to overcome the above described dilemma, ensuring cost effectiveness by price improvements on the one hand and also future sustainability for the business on the other. But even by the help of these experts, the projects outcome sometimes misses the intended objective. This could be due to the fact, that an accurate analysis of purchasing performance level (positioning) was not or at least insufficiently performed.

Based on the observation, that projects sometimes tend to fail to achieve their initial objectives two hypotheses are formulated:

$1^{\text {st }}$ Positioning of a purchasing organization is not or only inadequately assessed.

$2^{\text {nd }}$ Project goals are not achieved because the positioning of purchasing at project beginning is not or only insufficiently carried out, and the levers for optimization are not the leverage appropriate to the initial situation. 
In his articles about internal (Barth, 2017) and external factors (Barth, 2018) the author points out, that success of cost-reduction projects requires in the forefront of their execution continuing analysis, in order to determine the level of performance of a purchasing organization at the initial starting point of a project. Subsequently two models were derived from the requirements of a modern purchase to introduce industry proven performance aspects:

A 5-axis model of internal factors was established, consisting on the 5 factors of: Strategy, Employees (with subfactors Attitude and Skill), Organization, Process and systems, and Methods and tools. The model was extended by the consideration of externally acting challenges, showing external influencing factors on purchasing, depicted in the so-called 4-corner model, with the elements of: Corporate Organization, Purchasing Involvement and Embedding, Economy and Market.

With the help of a detailed literature research these models will be broader utilized, to evaluate the success of executed cost optimization projects and to enable a multiple view on the outcome results.

The aim of this paper is to derive a practical method for initial performance and status analysis of a purchasing organization which then can be applied and reviewed in cost-reduction programs.

\section{Current State of the Issue under Examination}

Main objective of this literature research was to identify current status of research on factors, which impact level of purchasing performance and cost optimization approaches for cost optimization programs in industrial purchasing. By reviewing literature of actual publications about purchasing driven cost optimization approaches, purchasing commodity strategies and consultancy approaches for cost optimization in purchasing, 4 main categories turned out to be predominant with following subjects:

- $\quad$ Purchasing maturity

- $\quad$ Performance factors

- Supply Chain Management related improvement studies

- Consultancy publications with project specific approaches

Out of numerous publications, a selection with typical predictions will be introduced. Keough (1993) reveals 5 barriers (poor information, weak administration, missing skills, lack of performance measures, purchasing low status) blocking organizations to move to strategic purchasing which leads to Carter's et al. (1996) question:" Is purchasing really strategic?", where he carried out, that strategic purchasing depends on competencies, tactics and strategy. Since purchasing organizations marched a long way and globalization enforced revised strategic lay out of organizations, which is mostly acknowledged in industry. In a more up to date paper van Poucke (2016) verifies the direct performance implication of purchasing maturity growth for social and economic related sourcing outcomes by proofing the correlation between organizational development stage and performance level. Hughes et al. (2016) render, that purchasing especially for intangible assets needs to drive values and thus has to revaluate strategies of the past towards the needs of an increasingly innovative driven and service-oriented Economy. Paik (2011) examines a connectivity of purchasing performance and company size and spend volume. Further publications e.g. De Waal et al. (2015) explore high performance partnerships related to high performing organization. Handfield et al (2015) link internal stakeholders need to supplier performance agreements, Lopez (2016), worked out a lack of department aligned strategies and Sharaaz (2016) considered inflation as profit influencing.

Supply chain management related publications link improvements to selected Methods and Tools. For example, Burroughs (2016) recommends alternative sourcing, Chia-Min and Chen (2008) examined transaction costs to achieve goals of cost minimization. Billington (2016) and Thompson (2016) reveal in their research the necessity of supplier relationship as a value managing strategy.

Consultancies offer their capabilities on homepages, where they publish recently successfully finalized cases. The information provided adverts the achieved objectives and provide facile information about the initial approach applied. This could be due to the fact, that consultancies do not wish to publish and share details of their unique selling approach. An integral view on approaches is also not provided.

Though it is not explicitly mentioned, the essence of the introduced publications is, that purchasing performance correlates with certain internal (within the purchasing organization sphere) and external (outside purchasing sphere) impact factors. Despite the need for a holistic view, the authors focus only on one or the other specific factor which proof evidence in the respective research area. Instead a methodology, which helps to describe the positioning of a purchasing organization entirely, is required to enable to select a project specific feasible cost optimization approach. 


\section{Methodology and Research Design}

During writing this paper multiple methods were applied. The examination is based on a qualitative research of necessary information by an executed internet and literature investigation of typical publications in the area of purchasing performance measurement, purchasing maturity or positioning from available consultancy information, journals, expert literature and business association. The aim was also to get a clear understanding and definition of the terms positioning and maturity. Focus was on comprehensive approaches offering a holistic examination of a purchasing organization's performance level and to review respective relevant criteria, rather than dealing with publications offering specific methods and approaches to improve a single performance aspect. Interesting questions are how to collect information, which kind of questionnaire is recommended and what kind of data analysis should be applied to assess purchasing performance.

The before carried out models (5-axis model, 4-corner model) and their respective internal and external factors are reviewed and mirrored with diverse publication's approach, analytic design and assumptions.

The findings are as well compared with the experience, knowledge and observations of the author (the author experienced more than 18 cost-reduction programs in industry). The outcome leads to the design of an assessment table in a matrix shape with further detailing of each factor in a descriptive manner and assigning maturity levels, accompanied by quantifiable measures.

Logical reasoning is applied to divide the matrix into two section of internal and external factors and set the factors in a logical order among the individual exposed internal and external factors. A further conducted literature research helped to complement the above derived tool with additional necessary environmental information through a PESTLE approach.

The tool is tested at three typical cost-reduction projects to verify the applicability and to confirm with the two above established hypotheses. Finally, the assessment matrix is validated through a semi-structured interview with 6 purchasing experts of the industry.

Ultimately synthesis of knowledge, analysis and deduction helped to carry out a comprehensive tool to measure purchasing performance level and allow for position reckoning of a purchasing organization.

\section{Purchasing Positioning Tool}

\subsection{Literature Research about Purchasing Maturity and Performance Evaluation}

\subsubsection{Positioning and Maturity}

A further and detailed literature research conducted carried out, that publications in the area of purchasing performance measurement, purchasing maturity or positioning range from a focus on specific single aspects to a holistic method for an entire performance positioning view. Before we look at respective literature it is important to note, that the term positioning from the view of this article has equal meaning to maturity, which is according to Rozemeijer et.al (2003) the level of professionalism in the purchasing function and that both illustrate the organizational performance status, considering typical characteristics. Thus, the terms will be used in parallel. Purchasing positioning is understood as an enabler for a purchasing performance increase. Based on the current positioning incremental savings should be identifiable as potentials, which lift positioning from current to a higher future and subsequently allow for higher performance level.

\section{Current Positioning $>$ Performance lift $>$ Future Positioning}

Figure 1. Improved Positioning by lifting performance, Source: Author

\subsubsection{Literature of the $90^{\text {th }}$ and Early $2000^{\text {nds }}$}

A number of reviewed publications belong to late $90^{\text {th }}$ or beginning of the millennium century. Most of introduced maturity models represent conceptional approaches. Keough (1993) illustrates that organizations achieve higher savings by reaching the next level. He identified 4 fields of improvements, which represent in generic terms a range of factors (competitive bidding, data transparency, cross functional collaboration, supply chain management). Ellram et al. (2002) support the hypothesis, that higher matured organizations apply more best practices by an executed correlation analysis of issued questionnaire to experts, which deals mainly with the application and meaning of purchasing and supply management and not with explicitly named factors. The assertions have not been substantiated by the authors and subsequently resulting performance improvements were not demonstrated. 
Sanchez et al. (2003) carried out a benchmarking analysis to provide insights about correlation of benchmarking to purchasing performance and business improvement. They demonstrate based on a questionnaire and applied statistical calculations that benchmarking in the area of supplier management is a valid tool, that positively impacts purchasing and business performance by e.g. on time delivery of purchase orders, achievement of inventory goals, timely response to internal customer inquiries and finally leads to overall internal customer satisfaction. Benchmarking as well as supplier management are elements of the before derived internal factors: Methods and Tools. The article explains only the contribution of one of the above introduced 5 internal factors and does not examine external factors to evaluate purchasing performance and subsequently does not serve for a holistic approach.

\subsubsection{Positioning Analysis by Benchmarking Utilizing Mathematic Tools}

\subsubsection{General Approach}

One of the more actual publications with a broader technique to purchasing positioning is a benchmarking analysis examined by Brandmeier and Rupp (2010) which is based on an interview guide to distil cause effect relationships between answers given and best practice lever usage in procurement, applying a statistical analysis utilizing mathematic tool of linear regression calculation to carry out correlation indicators between selected clusters and procurement levers (e.g. commercial, technical and supply chain process levers). The authors utilize 6 clusters, which are: strategy, organization, human resources, processes, Methods and Tools and finally supplier management. The considered factors are similar to the internal factors introduced above with a particular deviation in meaning and content and will be discussed below in the above shown order.

\subsubsection{Utilized Clusters}

The term strategy as the superordinate factor consisting on further internal factors contains development and application of actions to achieve purchasing related goals within a predicted period and bears identical meaning.

The authors see organization as the structure within procurement as well as its position within respective corporation, interaction with other corporate divisions and with the supply chain. This thesis uses organization in a more differentiated way and distinguishes internal and external factors to describe the various diverse effects and interdependencies on the interfaces (e.g. embedding, process flow, decision making).

Processes introduced by Brandmeier and Rupp cover elements like early involvement and make or buy decisions, which are regarded in "Methods and Tools" of this thesis. Whereupon the mentioned processes for order management, logistic and supplier quality refer to "system and processes".

Methods and tools as highlighted by Brandmeier and Rupp touch information management and e-procurement and thus are rather comparable to the definition of "system and processes of this thesis" and do slightly touch method and tools with the focus on cost optimization levers.

In comparison to the derived internal factor "employee" the authors use the term human resources for education, development and internationality, which is equivalent to the introduced subordinated terms attitude and competencies of "employee".

Supplier management is used as an independent factor by the authors, comprising all aspects from supplier selection over development to controlling and integration, whereas in this thesis it is not explicitly highlighted as an independent factor but regarded under sourcing concept as a method, offering cost optimization potentials if considered to enable for benchmarking and competitive sourcing.

The authors worked out 7 findings, which in summary show a significant dependency of the above describes clusters to success of a purchasing organization displayed below in 4 correlation groups:

1. Purchasing success correlates with organizational integration, cross functional interaction and training level of purchasing staff

2. Supplier integration and supplier evaluation influence purchasing success as well

3. Among all clusters a holistic staff development and training program is crucial for purchasing success of cross functional teams

4. Success of cross functional teams significantly correlates with organizational integration, interaction and overall application of purchasing levers

The authors use the discussed clusters to examine significance of factors to purchasing success, or in other words meaning of influencing factors in terms of purchasing positioning. In contrast to this thesis they do not distinguish between internal and external factors. Yet the clusters include all derived internal factors, though they might hold 
different titles and only deviate slightly in meaning. Such is for example cluster supplier management regarded in factor method and tools.

The highest correlation between clusters and purchasing success is with strategy (which is the same title as with the factors of this thesis) followed by supplier management (which is regarded in the factor method and tools of this thesis). Within cluster organization the aspect integration, which stands for cross functional teams, shows high significance for success. The ability for cross functionality is determined by training rather than education, and by organizational aspects like integration and interaction. Though the authors' aspiration was not to define a purchasing positioning tool, the findings confirm and support the 5-axis model of internal factors and even more help to identify the most important factors: Strategy, Organization, Training (as part of factor Employee) and application of Methods and Tools.

In terms of external influential factors Brandmeier and Rupp offer cluster organization, which can be considered together with its sub clusters integration or positioning within a corporation and interaction with other divisions. These are overlapping with the two external factors Corporate Organization and Purchasing Involvement and Embedding proving as well high significance. Beyond these further external influencing factors e.g. as market or economy are not introduced.

With the explored significance and correlation of clusters to purchasing success the authors support the idea of influential factors for purchasing positioning and maturity. A purchasing organization on higher maturity level will have more success than those operating on a lower level. The accountable factors, here highlighted as clusters, contribute significantly to purchasing positioning. It really makes a difference, from which positioning level a purchasing organization begins to raise its performance. High positioned organizations will need less and different improvement than those of a lower level. Hence, in order to measure purchasing positioning, these factors need to be considered and evaluated before starting a cost optimization project.

\subsubsection{Positioning Analysis by Benchmarking based on a Questionnaire}

In cooperation with management consultancy Oliver Wyman the BME (2016) offers within his benchmarking analytics recently a survey based on a questionnaire to examine procurement maturity and performance capacity. The objective in a first step is to reach out for manufacturing companies and to empirically establish a comprehensive benchmark catalogue. In a later stage the survey shall be extended to consider further industries as well. The maturity level of a purchasing organization will be analysed along 5 dimensions: Vision and Strategy, Organization, Processes, Personnel, Systems and Tools:

\begin{tabular}{|c|c|}
\hline Evaluation Dimension & Topics covered in the survey \\
\hline $\begin{array}{l}\text { Purchasing Vision } \\
\text { and Strategy }\end{array}$ & $\begin{array}{l}\text { - Definition of objectives and strategies } \\
\text { - Category and component strategies } \\
\text { - Challenges through digitalization }\end{array}$ \\
\hline $\begin{array}{l}\text { Purchasing } \\
\text { Organization }\end{array}$ & $\begin{array}{l}\text { - General and functional organization structure } \\
\text { - Roles and responsibilities, interface mangement } \\
\text { - Cross-functional cooperation }\end{array}$ \\
\hline $\begin{array}{l}\text { Purchasing } \\
\text { Processes }\end{array}$ & $\begin{array}{l}\text { - } \quad \text { Supply panel management } \\
\text { - } \quad \text { Process of information inquiry } \\
\text { - } \quad(\mathrm{RFI}) \text { / Request for quotation }\end{array}$ \\
\hline IV. $\quad \begin{array}{l}\text { Purchasing } \\
\text { Personnel }\end{array}$ & $\begin{array}{l}\text { - Employees ability and competences } \\
\text { - Purchasing career modell }\end{array}$ \\
\hline $\begin{array}{l}\text { Purchasing Systems } \\
\text { and Tools }\end{array}$ & $\begin{array}{l}\text { - } \text { Capacity of IT-Systems } \\
\text { - Spend and Supplier data storage } \\
\text { - Tools for supplier relation management }\end{array}$ \\
\hline
\end{tabular}

Figure 2. 5 Dimensions of purchasing maturity level

Their contribution to purchasing performance is aggregated in an evaluation matrix, which provides a quantified assessment of the analyzed purchasing organization. A questionnaire is available upon request by the BME Newsletter (2017). Interested position holders can enter their firm's data and issue for evaluation and feedback. 
The 5 dimensions are comparable but not congruent with the above introduced 5 internal influential factors. As with the article of Brandmeier and Rupp the content of dimensions strategy and vision fit with strategy of this thesis. Dimension organization of BME also includes cross functional cooperation. Organizational roles and responsibilities can be construed as organizational assimilable to Purchasing Involvement and Embedding in external factors. The area of Processes contains of course purchasing procedures but also includes Methods and Tools of internal factors. Besides attitude and competencies of staff career models are also included in Personnel in the BME's evaluation matrix. Dimension Systems and Tools matches with the terms of the respective internal factors. Alongside to dimension Organization further external factors are not disclosed.

\subsubsection{Positioning Analysis by Potential Indication}

Schiele (2017) examined in his article the development level of purchasing organization reached and its impact on business performance. Firms performance was measured by their success in a cost-reduction program, showing a highly significant relationship between maturity level and cost-reduction results. He primarily deduced his concept from dominant theory and tested the relation of maturity to performance empirically by conducting lever analysis workshops to identify saving potentials and mirror the outcome with a maturity analysis. Unexpectedly firms with higher maturity level showed larger saving potentials. The discovered effect he called absorptive capacity. This is due to the fact, that lower developed organizations fail in introducing latest state of the art and best practice approaches (probably because of lacking respective competences), which offer higher potentials than standard approaches. He disproves the popular assumption that lower positioned organizations disclose higher potentials for performance lift. The author also defines 5 dimensions of maturity profile: procurement planning, structural organization, process organization and embedding, human resources and purchasing controlling structures.

Similar to the publication above Schiele subsumes roles and responsibilities, interfaces and integration and participation in board meetings under organizational structure of purchasing. Thereby he combines the external and internal factor of Organization, Corporate Organization and Purchasing Involvement and Embedding. Dimension process organization includes elements of strategic sourcing, supplier development and involvement. Also, at this point the external factor cross functional purchasing involvement is considered. Dimension Human resources contains skills as well but is extended by consideration of recruiting, mechanism for performance appraisal and career development. In contrast to the before investigated articles Schiele incorporates further external elements like market and environment scan in his dimension procurement planning. For that matter he focuses rather on the existence of market and environment investigation than on detailed measures. In his fifth dimension: purchasing controlling, the author draws attention to the question of controlling system, processes, structure and methods to support controlling. These are reflected in the internal factor Processes and Systems.

In his article Schiele also refers to five dimensions which include the five internal factors, but in a different nomenclature. Besides the external factors Corporate Organization and Purchasing Involvement and Embedding he furthermore outlines the factor Market represented by the use of the term environment scan. The assumption that further external factors are analyzed in this case is not fulfilled. Rather, the questions of processing, available resources and cross functional integration for market analysis are illuminated. Schiele also established a questionnaire in the sense of an audit instrument to analyze purchasing positioning. His five dimensions are subdivided by 111 questions, are fully formulated by 4 stages of maturity, supported by a matrix of 444 explanatory fields to enable for reliability. Schiele stressed the fact that an external audit minimizes risk of bias and that two auditors conducted the interviews.

\subsubsection{Further Specific Approaches}

Beyond that numerous actual publications deal with topics of improvement of purchasing performance and offer resolutions for practitioners and academics in applying better cost effectiveness or dedicated supply management approaches. Though the subject of purchasing positioning is initial point, these publications focus rather on methods and approaches of improvement. Mentioned by way of example are Elram and Tate (2015) who elaborated a more effective and efficient way to purchase services. Garcia et al. (2013) developed a method to improve supplier selection processes and sustain supply chains. Halikas and Linktukangas (2016) investigated supplier and customer-oriented risk factors to derive appropriate risk management actions. A more to subject strategy related outcome is part of the work of Dewi et al. (2016). They defined a purchasing cost minimizing approach for collaborative organizations.

The gain in knowledge of these works lies rather in methodical or the processional improvement and thus offers only limited room for a holistic evaluation of purchasing maturity. 


\subsection{Assessment of Findings}

The literature research conducted examines that the authors used similar terms for internal and external factors as Barth $(2017,2018)$ derived in his articles with either slightly different meaning or negligible content deviation. The research content verifies the correlation between purchasing positioning (maturity level) and performance level and beyond the idea of factors, (the internal factors: Strategy, Employees, Organization, Processes and Systems, Method and Tools; external factors: Economy, Market, Purchasing Involvement and Embedding, Corporate Organization) and the causal context between purchasing organization positioning level (maturity) and its performance (success) got confirmed. Interestingly purchasing success was not measured by realized savings but indirectly by either knowledge about or deployment of profound purchasing levers, or as calculated potentials as outcome of conducted analysis workshops. Thus, the introduced approaches demonstrate the relationship of maturity to potential and theoretically achievable performance level, but fail to prove effectively realized savings as delivered performance indicator. Nevertheless, a syncrisis of indicated potentials across companies in comparison to the identified maturity level should provide reasons for higher success level, the higher the potential is. What is missing is an indication how reliable the estimation was. The ratio of actually realized savings in relation to the before indicated potential could answer that question. In other words, the authors use their tools to examine ex ante the value of expected performance. An ex post evaluation to confirm the indicated project potentials is missing. The reliability of potentials forecasted at the beginning of an optimization project is the core question regardless the maturity level. Consultancies tend to indicate potentials at a higher level to shape customers likelihood for a project start. This is all the more remarkable as Schiele (2007) disproves this banality in his essay.

Consequently, analysis of purchasing organization positioning prior to project beginning seems not only to be mandatory, to enable for an objective evaluation of purchasing capacity, but also requires profound understanding of the context of positioning and potentials. Indication of potentials should be carried out to the most realistic extent. For this, a comprehensive consideration of all internal and external influencing factors is required.

In contrast to this paper the authors do not distinguish between internal and external factors. Two dimensions of external factors are used: $1^{\text {st }}$ cross functional cooperation, represented by external factor Purchasing Involvement and Embedding, $2^{\text {nd }}$ roles and responsibilities represented by external factor Corporate Organization.

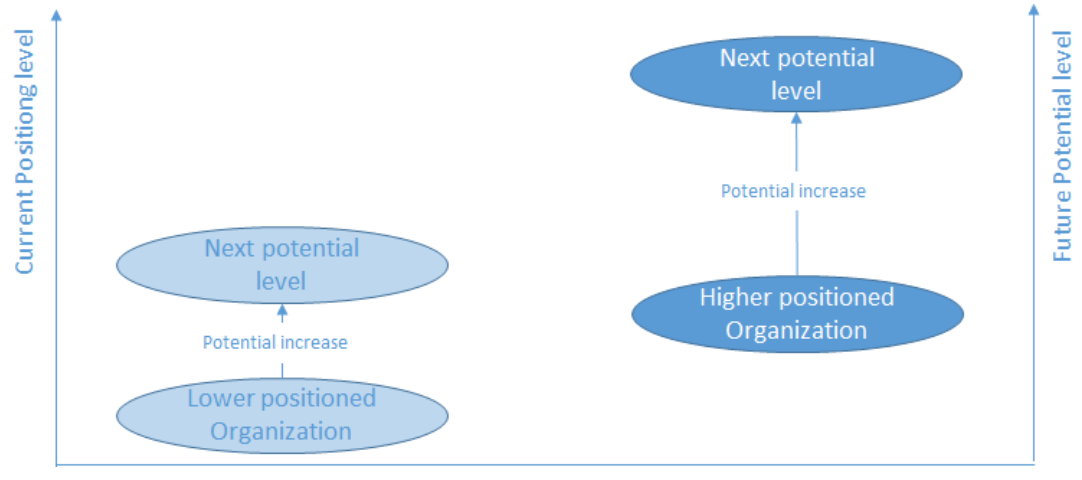

Figure 3. Correlation between purchasing positioning and potentials

Only Schiele (2007) makes an allowance for external factor Market. This leads to the conclusion that the instruments discussed provide rather a limited external purchasing view and leave external factor Economy out of scope. In order to assess the positioning of purchasing and evaluate the performance level one has to consider the economic environment (e.g. global finance crisis leads to shortage of bank credits, investment, and consumption, exchange rate drop causes price changes and impacts trade balance) as well. Thus, in addition an external view is important to put performance into perspective of influential environmental factors. 
The authors took two different approaches to proof the relationship of maturity level and purchasing performance as displayed in table 5. Questionnaires are either intended for self-assessment or audit by third party (Third party means externally to the department, e.g. consultants, interim Managers, external experts, experts from other departments, as long as the third party holds an independent view). Auditing has the advantage of higher reliability and less impact through bias of position holders.

Table 1. Purchasing maturity and performance assessment approaches

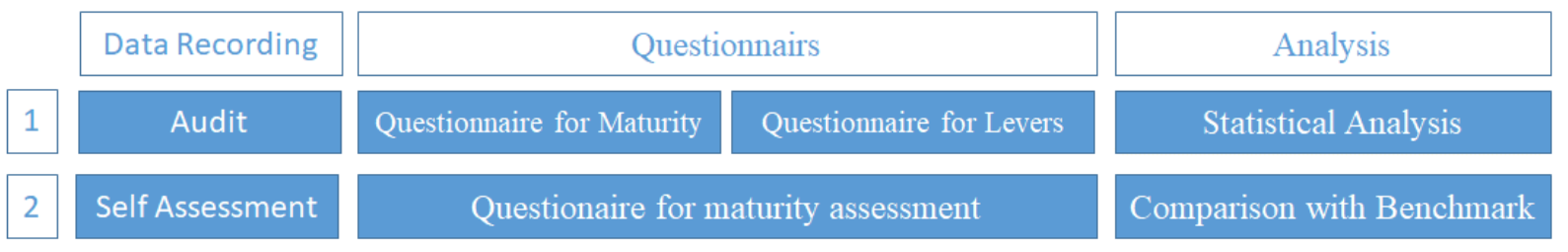

According to literature research performance analysis can be based on statistical analysis of maturity level and ability to apply value levers or a comparison of an examined maturity level with a benchmark, which served ex ante for an indication.

A designated tool should provide a holistic view on influential factors (internal and external), enable for maturity level analysis with rather quick applicability and easy to handle approach with the aim to allow a comparison of initial positioning, project objectives and achievement. It should cover internal and external factors and especially bear in mind environmental influencing aspects. More over a follow up analysis should be conducted ex post and allow for an evaluation of ex ante estimation and final realization. Therefore, a questionnaire should be applied by an external audit under utilization of a comparison with benchmarking.

Next chapter will introduce a tool to evaluate the positioning of a purchasing organization at the beginning of a cost optimization project.

\subsection{Derived Positioning Tool}

A tool for positioning evaluation of purchasing organization is intended to examine the maturity level of an organization and to identify which additional performance (performance lift can be measured in incremental or additional savings) increase against the current status can be achieved. Usually the status visualization is supported by spider diagrams, fever curves or even provided merely verbally. The aim of a tool to measure positioning is to base it on the previous findings of influencing internal and external factors. Both factor groups are detailed and complemented by before in this thesis introduced aspects. The shape of the tool conforms with a matrix. The matrix is divided in two areas for internal and external factors. The aspects per factor are supplemented by open questions, which allow qualified and graduated assessment of each factor. Each aspect per factor can be rated from level one to level four, whereas level one stands for poor maturity and level four for a professional purchasing organization. Total review of all aspects and assessment per level leads to a final evaluation and a quantifiable measure which indicates the level of maturity according to the 4 levels ranking. Within each level all 18 aspects will be evaluated and achieved score per level calculated.

Each factor section can be evaluated individually and allows distinguished assessment between the factors. The total amount computed across all levels represents the actual purchasing positioning (maturity level). The results per factor and entire positioning outcome can be transferred and displayed in graphical tools.

In summary the evaluation matrix (The author conducted more than 18 cost optimization projects across industries in various companies and evolved and utilized a matrix for initial purchasing maturity assessment) provides a tool which allows to assess each aspect per factor, supported by open questions in a graduated ranking from level one to four.

Besides the matrix to each factor verbal explanations should be attached, in case the detailing of the factors requires higher level of insights. Especially in the area of external factors deeper matter information could provide more clarity and give directions for decision makers. In his publication Crusciel (2011) carried out an approach to improve strategic business finding by scanning influencing information from business driving parties in the facility management business and points out the necessity to incorporate environmental information. Aldehayyat (2015) examined the importance of environmental scan and its contribution to business success and enhancement of performance. 
The results of his study show among others that with the political-legal and economic sectors (general factors) scanning focus was higher than for such as customer and competitors (task related factors).

Fabbe-Costes (2011) focused on aspects, that should be investigated to establish stable future supply chains. Applying a literature research in combination with collection of conducted case studies data and expert interviews she derived a collaborative scanning model examining the importance of social and legislation factors over technology.

A practical method fitting the requirement of applicability and the ability of supporting environmental scan is according to Team FME (2013) provided by the PESTLE approach. The phrase PESTLE represents the aspects of "Political, Economic, Social, Technological, Legal and Environmental" and can be used for business and strategic planning, marketing planning, organizational change, business and product development and research reports. Organizations can maximize the opportunities and minimize the threats, by understanding these external environments as they supplement the above described external factors of the matrix. It is recommended to complement the positioning tool by a PESTLE Analysis.

In the following chapter three typical in industry executed cost-reduction projects will be examined to understand the excellence of the respective applied approach in consideration of the above introduced purchasing positioning factors and to evaluate the achieved improvement of performance level. 


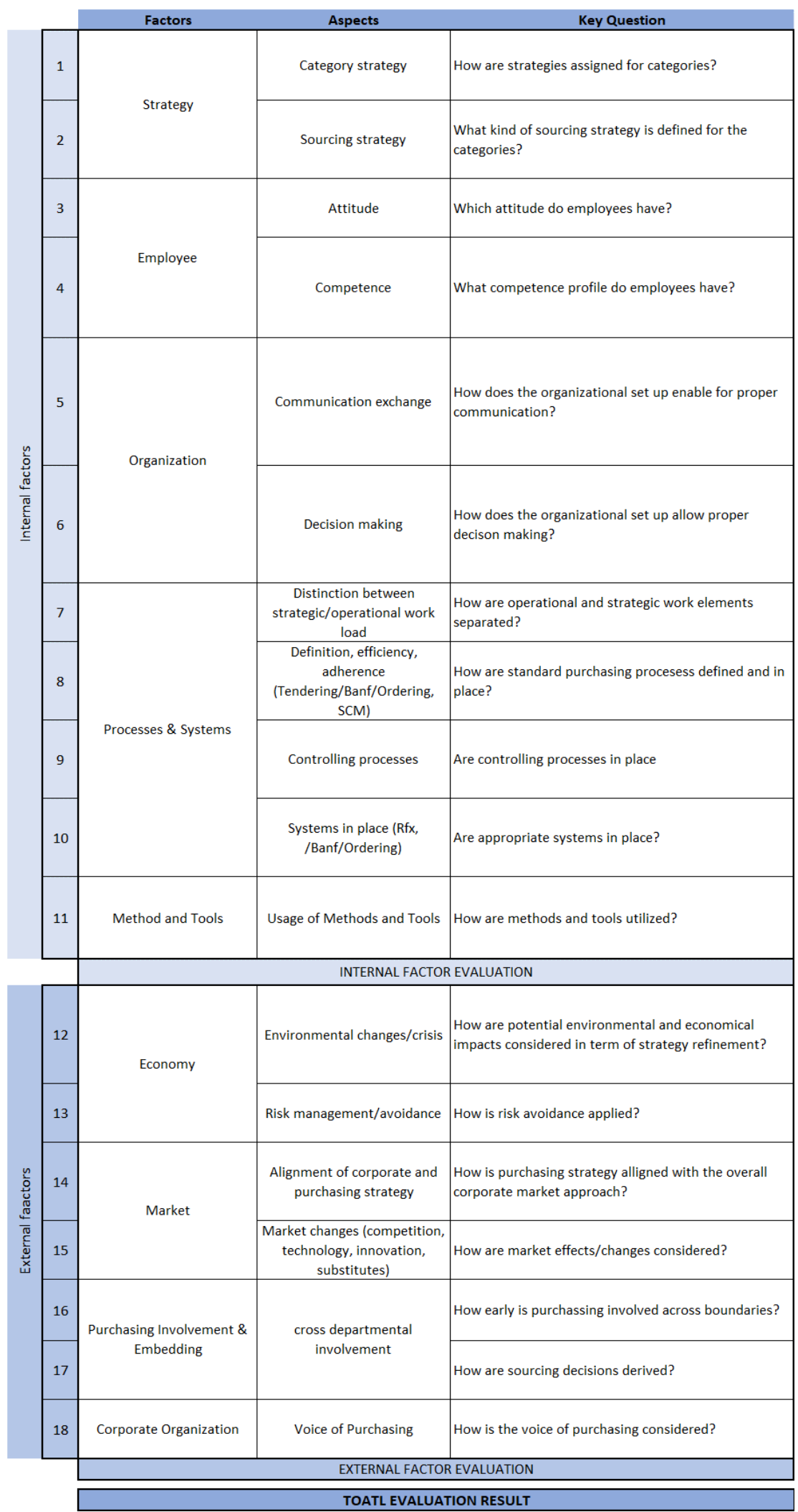

Figure 4. Purchasing positioning evaluation matrix part I 


\begin{tabular}{|c|c|c|c|}
\hline \multicolumn{4}{|c|}{ Level } \\
\hline 1 & 2 & 3 & 4 \\
\hline $\begin{array}{l}\text { Only few categories are handled by buyers, } \\
\text { strategies are not assigned }\end{array}$ & $\begin{array}{l}\text { Majority of Categories are overseen by } \\
\text { purchasing, strategies are refined for a few }\end{array}$ & $\begin{array}{l}\text { Total Category responsibility is assigned, } \\
\text { strategies are refined for most important } \\
\text { categories }\end{array}$ & $\begin{array}{l}\text { For all categories a responsible buyer is } \\
\text { assigned and a comprehensive global } \\
\text { strategy is refined }\end{array}$ \\
\hline $\begin{array}{l}\text { Almost no sourcing strategy in place, } \\
\text { subject area sources according demand }\end{array}$ & $\begin{array}{l}\text { Basic sourcing ideas in place for some } \\
\text { categories, mainly driven by subject area, } \\
\text { purchasing can make suggestions }\end{array}$ & $\begin{array}{l}\text { General sourcing strategies for main } \\
\text { categories refined by subject area and } \\
\text { purchasing }\end{array}$ & $\begin{array}{l}\text { Dedicated sourcing strategies assigned to } \\
\text { most important categoreis according to } \\
\text { business impact and significance, alligned } \\
\text { with subject area }\end{array}$ \\
\hline $\begin{array}{l}\text { Employees have low peculiarity of } \\
\text { purchasing specific attitude }\end{array}$ & $\begin{array}{l}\text { Employees have basic peculiarity of } \\
\text { purchasing specific attitude }\end{array}$ & $\begin{array}{l}\text { Employees have advanced peculiarity of } \\
\text { purchasing specific attitude }\end{array}$ & $\begin{array}{l}\text { Purchasing staff is highly addicted to } \\
\text { purchasing and bears all necessary } \\
\text { characteristics }\end{array}$ \\
\hline $\begin{array}{l}\text { Employees show low competence profile } \\
\text { in terms of knowledge of modern } \\
\text { methods and tools of subject and } \\
\text { interpersonal relationship }\end{array}$ & $\begin{array}{l}\text { Employees show intermediate } \\
\text { competence profile in terms of knowledge } \\
\text { of modern methods and tools of subject } \\
\text { and interpersonal relationship }\end{array}$ & $\begin{array}{l}\text { Employees show adequate competence } \\
\text { profile in terms of knowledge of modern } \\
\text { methods and tools of subject and } \\
\text { interpersonal relationship }\end{array}$ & $\begin{array}{l}\text { Purchasing staff is highly educated and owns } \\
\text { knowledge of modern methods and tools of } \\
\text { subject and interpersonal relationship }\end{array}$ \\
\hline $\begin{array}{l}\text { Purchasing organization works rather in } \\
\text { isolation, communication within and to } \\
\text { and from external partners is difficult due } \\
\text { to lack of structured assignment of } \\
\text { responsibilities and tasks }\end{array}$ & $\begin{array}{l}\text { Purchasing organization is to some extent } \\
\text { structured according customer } \\
\text { departments need, communication rather } \\
\text { based on network than on structure }\end{array}$ & $\begin{array}{l}\text { Purchasing organization is structured } \\
\text { according customer departments need, } \\
\text { communication follows functional } \\
\text { assignment }\end{array}$ & $\begin{array}{l}\text { Purchasing organization has clear } \\
\text { commodity structure, is easy assessible, } \\
\text { communication to, within and to external } \\
\text { partners is well established, clear assignment } \\
\text { of responsibilities }\end{array}$ \\
\hline $\begin{array}{l}\text { Decision making for the majority of all } \\
\text { purchasing cases takes rather long time } \\
\text { and decision making process is entirely } \\
\text { intransparent }\end{array}$ & $\begin{array}{l}\text { Decision making for some purchasing } \\
\text { cases takes partially rather long time and } \\
\text { decision making process is partially } \\
\text { intransparent }\end{array}$ & $\begin{array}{l}\text { Decision making process for a few } \\
\text { purchasing cases takes rather long time } \\
\text { and decision making process for majority } \\
\text { of purchasing cases is known }\end{array}$ & $\begin{array}{l}\text { Decision making process is well known for } \\
\text { purchasing cases within the organization in } \\
\text { tmss of duration, decision making assigned } \\
\text { to established committees, which convene } \\
\text { on regular basis }\end{array}$ \\
\hline $\begin{array}{l}\text { Strategic and operational work elements } \\
\text { are not distinguished and staff has to do } \\
\text { all of it }\end{array}$ & $\begin{array}{l}\text { Some operational work is assigned to } \\
\text { assistants, remaining work content } \\
\text { distributed among staff }\end{array}$ & $\begin{array}{l}\text { Some strategic work content is assigned to } \\
\text { strategic buyers, assistants support in day } \\
\text { to day business }\end{array}$ & $\begin{array}{l}\text { Clear organizational distinction and } \\
\text { assignment of strategic and operational } \\
\text { tasks to staff }\end{array}$ \\
\hline $\begin{array}{l}\text { Few processes defined and documented, } \\
\text { customer department applies own } \\
\text { procedures }\end{array}$ & $\begin{array}{l}\text { Basic processes defined, poor } \\
\text { doumentation and alignment with } \\
\text { customer department, poor adherence by } \\
\text { customer departments }\end{array}$ & $\begin{array}{l}\text { Major porcesses defined and documented, } \\
\text { aligned with customer department, } \\
\text { adherencefor these given }\end{array}$ & $\begin{array}{l}\text { Living purchasing processes in place, defiend } \\
\text { and documented, alligned customer } \\
\text { departments, high level of adherence }\end{array}$ \\
\hline $\begin{array}{l}\text { Almost no controlling instruments in } \\
\text { place, no alignment with corporate } \\
\text { functions }\end{array}$ & $\begin{array}{l}\text { Basic measures established and } \\
\text { monitored, rather used within purchasing } \\
\text { community }\end{array}$ & $\begin{array}{l}\text { Some measures established, monitored } \\
\text { and shared with customer departments, } \\
\text { review of key metrics }\end{array}$ & $\begin{array}{l}\text { Controll panel established and aligned with } \\
\text { corporate representing major important } \\
\text { measures, frequently updated and presented } \\
\text { to allow strategey adjustments }\end{array}$ \\
\hline $\begin{array}{l}\text { Various systems in place or system does } \\
\text { not represent purchasing processes, no } \\
\text { patency across department boarders }\end{array}$ & $\begin{array}{l}\text { Some processes represented by systems, } \\
\text { limited patency across departmental } \\
\text { boarders }\end{array}$ & $\begin{array}{l}\text { Main processes represented by systems, } \\
\text { partially netted, allow some patency } \\
\text { across departmental boarders }\end{array}$ & $\begin{array}{l}\text { Systems repesent and support purchasing } \\
\text { processes, are netted, allow patency and } \\
\text { transfer of information across department } \\
\text { boarders }\end{array}$ \\
\hline $\begin{array}{l}\text { Poor application of modern tools and } \\
\text { methods }\end{array}$ & $\begin{array}{l}\text { Basic tools and methods are applied on } \\
\text { selected categories }\end{array}$ & $\begin{array}{l}\text { Some Tools and methods are in use for } \\
\text { major business important categories }\end{array}$ & $\begin{array}{l}\text { Modern Tools and methods are well known } \\
\text { in the purchasing organization and are } \\
\text { utilized to the best possible extent }\end{array}$ \\
\hline POOR 0 - 11 & BASIC $12-22$ & ADVANCED $23-33$ & PROFESSIONELL 34 - 44 \\
\hline $\begin{array}{l}\text { Environmental and economical impacts } \\
\text { are insufficiently considered }\end{array}$ & $\begin{array}{l}\text { Basic economical impacts are part of the } \\
\text { strategy refinement, environmental } \\
\text { changes rather insufficiently considered }\end{array}$ & $\begin{array}{l}\text { Basic economical and environmental } \\
\text { impacts are part of the strategy } \\
\text { refinement }\end{array}$ & $\begin{array}{l}\text { Potential impacts (e.g. } \\
\text { environmental/financial crisis, technological } \\
\text { changes) are considered to the most possible } \\
\text { extent in strategy refinement and execution }\end{array}$ \\
\hline Risk avoidance is insufficently applied & $\begin{array}{l}\text { Mitigating actions are contemporary } \\
\text { initiated upon occurance of crisis }\end{array}$ & $\begin{array}{l}\text { Economy and market impact surveillance } \\
\text { and definition of mittigating actions }\end{array}$ & $\begin{array}{l}\text { Proactive risk identification instruments are } \\
\text { in place and mitigating action plan is } \\
\text { established }\end{array}$ \\
\hline $\begin{array}{l}\text { Purchasing strategy does not consider } \\
\text { corporate market appoach }\end{array}$ & $\begin{array}{l}\text { Purchasing strategy considers to some } \\
\text { extent corporate market approach }\end{array}$ & $\begin{array}{l}\text { Purchasing strategy considers to some } \\
\text { extent corporate market approach }\end{array}$ & $\begin{array}{l}\text { Purchasing strategy is in line with the overal } \\
\text { corporate market and business approach } \\
\text { and are considered for most of the } \\
\text { categories }\end{array}$ \\
\hline $\begin{array}{l}\text { Market changes are insufficiently } \\
\text { considered }\end{array}$ & $\begin{array}{l}\text { Market changes are occasionally reviewed } \\
\text { and considered for few categories }\end{array}$ & $\begin{array}{l}\text { Market changes are frequently reviewed } \\
\text { and considered for some categories }\end{array}$ & $\begin{array}{l}\text { Actual market changes are steadily } \\
\text { monitored and incorporated into strategies }\end{array}$ \\
\hline Purchasing administers ordering process & $\begin{array}{l}\text { Purchasing involved in project team } \\
\text { meetings at medium or later stage }\end{array}$ & $\begin{array}{l}\text { Purchasing involved in project team } \\
\text { meetings at medium stage }\end{array}$ & $\begin{array}{l}\text { Mutuall team approach, purchasing involved } \\
\text { in early stage of budget planning }\end{array}$ \\
\hline $\begin{array}{l}\text { Purchasing is administering, desicions are } \\
\text { purly made by subject area }\end{array}$ & $\begin{array}{l}\text { Purchasing can partially make minor } \\
\text { proposals, decision by subject area }\end{array}$ & $\begin{array}{l}\text { Purchasing can contribute to an } \\
\text { overseeable content }\end{array}$ & $\begin{array}{l}\text { Mutuall team approach, decisions are } \\
\text { mutually made in allignment meetings } \\
\text { considering overall purchasing strategies }\end{array}$ \\
\hline $\begin{array}{l}\text { Purchasing reports to subject area with no } \\
\text { access to decision makers }\end{array}$ & $\begin{array}{l}\text { Purchasing reports to subject area with } \\
\text { access to decsion committee }\end{array}$ & $\begin{array}{l}\text { Purchasing reports to subject area with } \\
\text { access to decsion committee and } \\
\text { executives }\end{array}$ & $\begin{array}{l}\text { Purchasing is board member or reports } \\
\text { directly to the board }\end{array}$ \\
\hline Poor $0-7$ & BASIC $8-14$ & ADVANCED $15-21$ & PROFESSIONAL $22-28$ \\
\hline Poor $0-18$ & BASIC $19-36$ & ADVANCED $37-54$ & PROFESSIONAL 55-72 \\
\hline
\end{tabular}

Figure 5. Purchasing positioning evaluation matrix part II 


\section{Evaluation of Approach}

\subsection{Three Typical Cost Optimization Projects in Industry}

At three cost optimization projects the maturity level of each organization was evaluated to demonstrate the initial performance level and to proof the initial hypotheses.

Assessed cost optimization projects took place at an agriculture manufacturer at OEM level and at suppliers with Tier-1 or Tier-2 status in automotive, truck and rail industry. The corporations investigated had in common cost optimization of externally manufactured production components. In all cases projects initiators were at top management or purchasing heads with top management involvement, who wanted to increase purchasing performance.

Project execution was either with a consultancy or external experts, whereas experts accounted for a managerial position and the task to initiate cost optimization activities in combination with the task to manage respective categories.

In all three projects data analytics for potential identification and calculation at project beginning was applied facilely by the project initiators. Achievable saving potentials forecasted were explicitly overestimated in two conducted projects either by consultancy to suit customer expectations or by purchasing management (recently hired $\mathrm{CPO}$ ) itself to fit top management's requirements and ease project release process, or was not defined but in general expected as additional outcome. The positioning of the purchase at the beginning of the project was not carried out at all or insufficiently executed by the project owners and let to a significant deviation between forecasted potentials and achieved savings. The outcome proofs the first hypothesis: Positioning of Purchasing Organization is not or only inadequately performed, as true.

\subsection{Application of Positioning Tool at Project Start}

The author applied the above examined positioning tool in each project before project start when he joined the project team to gain more insights than carried out by the project owners before. Astonishingly external factors achieved almost the same rating as internal factors from each organization, though there was room for improvements in this area. Especially proactive risk measures were poorly considered. Lowest level assessed projects showed poorest achievements, but even highest positioned organization failed its forecasted numbers. Compared with the findings of Schiele (2007) the lower positioned automotive tier-2 organization as well had less capability to achieve potentials, where by contrast the analysis of automotive tier- 1 supplier did not end up with higher potentials nor realized higher results. This could be due to the fact, that the tier-1 supplier organization had recently successfully utilized all feasible cost optimization levers and the repetition of comparable approaches harbors significantly less potential. So, this example gives evidence, that indicated potentials do not necessarily match with realized savings.

Consultancy or management had a bias on method and tools selected for the project which failed to provide initially calculated saving offerings. This could be due to the fact of good experience from earlier projects or even none combined with infinite confidence in capability of external know-how. Besides commercial objectives further goals were only partially achieved. Indeed, there were gains like new invented methods and know-how transfer to customer staff, but other intangible objectives were not met. Reason for failure of inappropriate methods were mismatch of know-how and experience of organization, not regarded culture or inappropriate market approach.

All together the examination affirms the second hypothesis, that project goals are not met, because of either no or faulty assessment of purchasing positioning and selection of inappropriate optimization levers.

The applied positioning assessment based on the introduced matrix complemented by a PESTLE evaluation gave good indications of the performance level of each organization at project beginning.

\subsection{Application of Positioning Tool at Project Closure}

At project closure the assessment was conducted again. A purchasing performance increase could be identified at all projects. The better positioned organizations achieved a raise of $22-28 \%$, whereas the low evaluated tier-2 supplier came up with $16 \%$ performance increase. Though there was no initial saving indication the original lower performing purchasing community of the tier- 2 achieved only a marginal return on project costs of $25 \%$. In contrast, the agriculture OEM and automotive Tier-1 realized factors between 2,53 and 4,08 (see figure 6," Assessment overview of investigated projetcs"). These findings supplement the general expectation, that better positioned organizations achieve higher results. It appears, that below level 2 evaluated organizations in the range between level 1 and 1,5 indicate significant low performance level and low ability for organizational improvement. This is especially valid in the field of external factors of the Tier-2 supplier, where no improvement could be identified whereas the other 
projects showed a verifiable lift. Though the selected projects do not represent a significant number of projects, at least the implication based on these three allow the assumption, that rating explicitly below level 2 of the assessment matrix is a performance threshold and could be subject of further future project research.

\begin{tabular}{|c|c|c|c|c|}
\hline$\#$ & Aspect & Agriculture Manufacturer & Tier-1 Truck and Railway & Tier-2 Automotive Supplier \\
\hline & Qualifiable MEASURES & Entry & Entry & Entry \\
\hline 1 & Value stream level & OEM & Tier-1 & Tier-2 \\
\hline 2 & Industry & Agriculture & Automotive / Truck & Automotive \\
\hline 3 & Project Initiator & Management, Purchasing & Management, Purchasing & Management, Purchasing \\
\hline 4 & Executor & $\begin{array}{c}\text { Consultancy with support of } \\
\text { external Experts }\end{array}$ & External Experts & External Experts \\
\hline 5 & Objectives & $\begin{array}{l}\text { Saving number, build up } \\
\text { global organization }\end{array}$ & Saving number, team lead & $\begin{array}{l}\text { Saving number, ramp up } \\
\text { tool, strategy refinement }\end{array}$ \\
\hline 6 & Initiator of objectives & Consultancy & Purchasing management & Purchasing management \\
\hline 7 & Positioning Assessment & $\begin{array}{c}\text { Not applied by consultancy } \\
\text { or customer }\end{array}$ & Not applied by customer & Not applied by customer \\
\hline 11 & Applied Approach & $\begin{array}{l}\text { Consultancy standard tool } \\
\text { box }\end{array}$ & $\begin{array}{l}\text { A set of feasible tools and } \\
\text { methods applied }\end{array}$ & Limited tool set applied \\
\hline 12 & Achievments vs. Objectives & $\begin{array}{c}\text { Forecasted Savings not } \\
\text { achieved, result significant } \\
\text { below expectations }\end{array}$ & $\begin{array}{l}\text { Forecasted Savings not } \\
\text { achieved }\end{array}$ & $\begin{array}{l}\text { Forecasted Savings not } \\
\text { achieved }\end{array}$ \\
\hline 13 & Additional winnings & Know How Transfer & Know How Transfer & Know How Transfer \\
\hline 14 & Pecularities & $\begin{array}{c}\text { Not perfectly suiting } \\
\text { approach, missing stringent } \\
\text { work through and consitent } \\
\text { roll out }\end{array}$ & $\begin{array}{l}\text { Low staff motivation, low } \\
\text { sustainability level in } \\
\text { previous applied } \\
\text { approaches, demotivated } \\
\text { supply chain, less time } \\
\text { availability }\end{array}$ & $\begin{array}{l}\text { Unstructured organization } \\
\text { and processes, } \\
\text { overwhelmed supply base }\end{array}$ \\
\hline & Quantifiable MEASURES & VALUES & VALUES & VALUES \\
\hline 15 & Saving Ratio $=\frac{\text { Saving indicated }}{\text { Saving realized }}$ & 2,34 & 2 & not applicable \\
\hline 16 & Effectivness Ratio $=\frac{\text { Saving realized }}{\text { Project costs }}$ & 4,08 & 2,53 & 0,252 \\
\hline 17 & Level Positioning Assessment 1 & 2,17 & 2,5 & 1,34 \\
\hline 18 & Points Total & 39 & 45 & 25 \\
\hline 19 & Level Internal Factors & 2,18 & 2,45 & 1,55 \\
\hline 20 & Points Internal Factors & 24 & 27 & 17 \\
\hline 21 & Level External Factors & 2,14 & 2,57 & 1,14 \\
\hline 22 & Points External Factors & 15 & 18 & 8 \\
\hline 23 & Level Positioning Assessment 2 & 2,78 & 3,06 & 1,61 \\
\hline 24 & Points Total & 50 & 55 & 29 \\
\hline 25 & Level Internal Factors & 2,73 & 3,09 & 1,91 \\
\hline 26 & Points Internal Factors & 30 & 34 & 21 \\
\hline 27 & Level External Factors & 2,86 & 3,00 & 1,14 \\
\hline 28 & Points External Factors & 20 & 21 & 8 \\
\hline 29 & Level Positioning ratio $=\frac{\text { Pos } 2}{\text { Pos } 1}$ & 1,28 & 1,22 & 1,16 \\
\hline
\end{tabular}

Figure 6. Assessment overview of investigated projects

Interestingly the assessment and especially an accurate data analysis was not considered at the displayed detail level by the project owners.

The initial and achieved objectives deviated significantly and later on selected methods and tools to increase saving ratio did partially support the realization of predicted potentials. It also turned out that management and consultancy had preferences in selection of approaches to execute cost optimization projects which did not suit the positioning of a purchasing organization nor achievement of results. 


\subsection{Validation by Semi-Structured Interview}

Eventually the positioning tool was validated through a semi-structured interview conducted with 6 purchasing experts. The interviewees were asked to review the examined approach under the aspect of logic and applicability and to compare with their practical observation and knowledge and feedback in a conversational style along a prepared conversation guide. When asked to partake they were eager to learn about thesis' findings and to bring in their own point of view for verification of deduced approach. The experts age ranged from 34 to 59 with an average of 49 years. Five of them were self-employed, one employed as consultant. On average they had 12,5 years of experience in the subject matter and experienced more than 13 projects on average. All together 75 years of project experience were represented. Besides one, who participated in two projects, the others had already filled leading positions in cost-reduction programs. Four of them hold an academic degree in industrial engineering or business administration, two gained specific purchasing related awards by professional training. All participants spend on average more than 25 years in business and 16,5 years in purchasing. These numbers represent requirements on senior management positions in industry. All of them are experienced in working on managerial level. As the approach is intended for application in different categories the experience in various fields, indirect services and material, Capex or investment and machinery and building, direct or production material is appreciated. The experts covered all three typical fields, of which Capex is represented by over $84 \%$ of all interviewees, whereas Indirect and Opex have a representation of 2 third. The figures demonstrate high level of experience coverage in major relevant commodities. 9 different industries are mapped by the experts under which automotive gained highest representation with $100 \%$ representation, followed by Agriculture with $83 \%$ and Mechanical Engineering with 67\%. House equipment, Aviation, Furniture industry and Banking business indicate less often covered industry sectors. The experts possess in addition know-how in international projects, at OEM and Tier-1 and Tier-2 level, in outsourcing projects, as well as in various methods like global sourcing, make or buy analysis, cost break down analysis. One of the participants leads a consultancy specialized in supply chain management and purchasing. All interviewees were active in current assignments in cost optimization or restructuring projects at time of interview conduction.

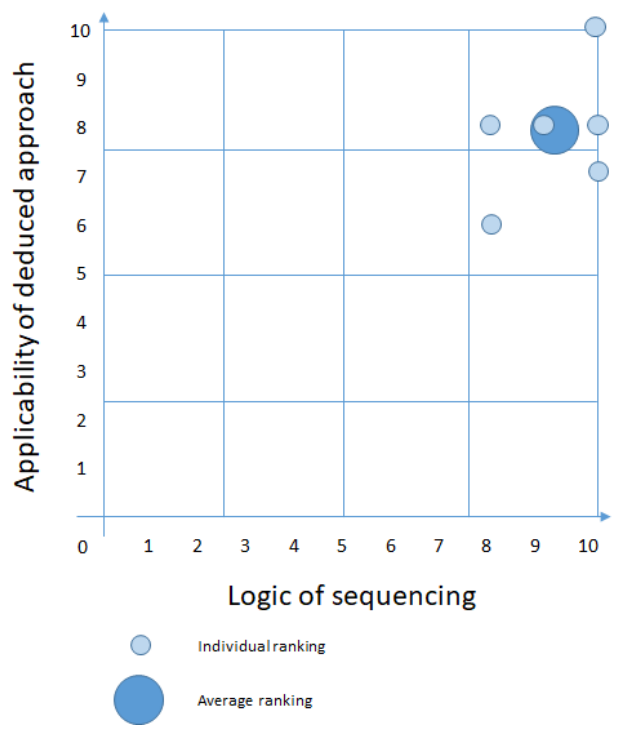

Figure 7. Expert evaluation of deduced approach

The matrix was evaluated as valid tool to analyze purchasing positioning and the hypotheses were attested as a good fit with interviewees observation, logically sequenced, comprehensive and well formulated. The experts evaluated the logic of sequencing on average with 9,17 and applicability with 7,83 .

The interviewees confirmed the necessity to align purchasing and company strategy and to strive for high level of purchasing embedding (See 4-corner model of external factors). The partition in internal and external factors, respective aspects and displayed questions were positively validated and the applied seen as suitable. The semi-structured interview turned out as suitable format for evaluation of deduced approach by experts. 


\section{Results and Discussion}

This paper examined a purchasing positioning tool to assess purchasing performance level at or before project beginning. Two hypotheses were set up before from deduced empirical observation and were confirmed by the execution and outcome of the projects and the experts' interview. Starting point were the afore derived and established 5-axis and 4-corner-models of internal and external factors, following an in-depth literature research for a holistic evaluation approach of purchasing organization maturity assessment. Findings were that a designated tool should provide a comprehensive view on influential factors (internal and external), enable for maturity level analysis with practical approach with the aim to allow a comparison of initial and final positioning and achievement.

Interestingly, in contrast to this paper, the investigated literature does not distinguish between internal and external factors. Two dimensions of external factors are used: $1^{\text {st }}$ cross functional cooperation, represented by external factor Purchasing Involvement and Embedding, $2^{\text {nd }}$ roles and responsibilities represented by external factor Corporate Organization. Only Schiele (2007) makes an allowance for external factor Market. This leads to the conclusion that the instruments discussed provide rather a limited external purchasing view and leaves external factor Economy out of scope.

The derived models (5-axes model, 4-corner model) served as a very good basis to split the matrix in two sections of internal and external evaluation aspects. The tool details factors in further aspects and especially includes environmental influencing aspects. In order to assess the positioning of purchasing and evaluate the performance level the economic environment (e.g. global finance crisis leads to shortage of bank credits, investment, and consumption, exchange rate drop causes price changes and impacts trade balance) was considered as well. Thus, in addition an external view is important to put performance into perspective of influential environmental factors.

Astonishingly, the authors investigated purchasing performance of respective organizations only ex ante at project beginning, but not ex post at project end to verify the achievement level of selected approaches. Hence, a follow up analysis is required, which allows for an evaluation of ex ante estimation and finally realized achievement level.

Therefore, a questionnaire is designed, split in two main sections of 5 internal and 4 external factors, with totally detailing of 18 evaluation aspects. The evaluation follows a 4-step assessment from a as "poor" up to a as "professional" graded organization with a range of $0-72$ points assigned. Each factor section can be assessed individually and finally aggregated to an overall evaluation. The assessment is conducted by an external audit and can be extended by spend data analysis under use of a comparison with benchmarking.

It is recommended to widen the positioning analysis through an environmental analysis according to the PESTLE (political, environmental, technological, legal, economical)-approach, in order to gain the biggest possible insight of potential influencing factors.

Finally, the approach was positively verified in three cost optimization projects and ultimately through a semi-structured interview with 6 purchasing experts.

\section{Study Limitation and Conclusion}

The tool was validated by three industry projects. Branches were automotive, truck and rail. Companies are positioned as OEM, Tier-1 and Tier-2 supplier, obtaining global or at least international footprint. All manufacturers have dependencies on external supply chains, with which they have to manage respective costs. Requirements to a typical purchasing organization of these companies are comparatively high, because external value creation is about $50 \%$ and above and causes significant business impact. Though there were only three projects considered, the ambitious purchasing environment, afore confirmed hypotheses and the outcome of six conducted semi-structured interviews support the assumption of typical project representation in manufacturing industry (the author observed and participated in more than 18 projects of which these selected three provide representative insights). Meanwhile the tool has also been positively validated in two further projects of energy producing and seed production industry. It is recommended to investigate tool's applicability in non-production or service-oriented industries as well. Also, a potential threshold of performance increase at ratings below "2" could be subject of further projects with low positioned purchasing organizations to investigate cause effect relation of positioning and potentials of performance increase.

The elaborated tool is to be understood as an instrument for initial analysis of a purchasing organization's performance level in order to help select and develop suitable and appropriate instruments for sustainable cost optimization. The tool is designed for application in context of a holistic cost optimization approach (which is subject of further research) as one of the elements in the early project phase of analysis. It can help to substantiate 
savings prediction at project beginning and increase level of saving forecast reliability combined with sufficient data analysis.

The tool can also help to measure the achieved performance increase, once assessment is conducted after project execution. Besides tangible measures like savings, quality betterment or payment improvement, even intangible measures like purchasing embedding, strategy refinement or consideration of economic impact factors can be assessed and necessary changes for future security be derived.

Intended as integral part of a cost optimization project to be applied in the analysis phase, the outcome of the tool could also help to optimize target-oriented selection of appropriate approaches and methods in order to increase project efficiency and minimize waste of capacities, time and expenditures.

\section{References}

ALEDEHAYYAT J. S. (2015). Environmental scanning in business organisations: Empirical evidence from a Middle Eastern country context. Management Research Review, 38(5), 459-481. https://doi.org/10.1108/MRR-02-2014-0032

BARTH J.A. (2018). Influencing Purchasing Positioning - Deriving a Model Based on External Factors. Journal of Business and Economic Development, 3(1). http://www.sciencepublishinggroup.com/journal/paperinfo?journalid=297\&doi=10.11648/j.jbed.20180301.12

BARTH J.A. (2017). 5 Axis model - Which internal factors influence purchasing performance level. 16th International Scientific Conference. Comenius University Bratislava, Management Faculty.

BILLINGTON, C., SANDOR, J. (2016). Who's kidding who? your strategy should get you fired. Supply Chain Management Review, 20(1), 22-27.

BME (2016). Neuer Benchmark, den Reifegrad des Einkaufs messen. https://www.bme.de/neuer-benchmark-den-reifegrad-des-einkaufs-messen-1538/

BME NEWSLETTER (2017). BME-Benchmark-Services, Benchmark Reifegrad und Leistungsfähigkeit des Einkaufs. http://bme.newsletter-service.eu/i/uNicC6Mt1RDQwrZ1glSPh5eLuFlkRR_3

BRANDMEIER R.A., RUPP F. (2010). Benchmarking procurement functions: causes for superior performance. Benchmarking: An International Journal, 17(1), 5-26. https://doi.org/10.1108/14635771011022299

BURROUGHS A. (2016). Advanced buying strategies. Smart Business Akron/Canton, 25(9), 68. https://search.proquest.com/docview/1779892889?accountid=59680

CARTER, J. R., NARASIMHAN, R. (1996). Is purchasing really strategic? International Journal of Purchasing and Materials Management, 32(1), 20-28. https://doi.org/10.1111/j.1745-493X.1996.tb00216.x

CHIA-MIN W., CHEN, C. (2008). An empirical study of purchasing strategy in automotive industry. Industrial Management \& Data Systems, 108(7), 973-987. https://doi.org/10.1108/02635570810898026

CHRUSCIEL D., (2011). Environmental scan: influence on strategic direction. Journal of Facilities Management, 9(1), 7-15. https://doi.org/10.1108/14725961111105691

DE WAAL A., GOEDEBURGER R., HINFELAAR E. (2015). Developing a scale for measuring high performance partnerships. Journal of Strategy and Management, 8(1), 87-108. https://doi.org/10.1108/JSMA-07-2014-0065

DEWI S., BAIGHAGI I., WIDOD E. (2016). Modeling Pooled Purchasing Strategy in Purchasing Consortium to Optimize Total Purchasing Cost. Procedia Manufacturing, 4, 2015, 478-486. https://doi.org/10.1016/j.promfg.2015.11.065

ELLRAM L.M., TATE W.L. (2015). Redefining supply management's contribution in services sourcing. Journal of Purchasing and Supply Management, 21(1), 64-78. https://doi.org/10.1016/j.pursup.2014.10.001

ELLRAM L.M., ZSIDISIN G.A., SIFERED Perrot S., STANLEY M.J. (2006). The impact of purchasing and supply management activities on corporate success. The Journal of Supply Chain Management, 38(4), 4-17. https://doi.org/10.111/j.1745-493X.2002.tb00116.X

FABBE-COSTES N., ROUSSAT C., COLIN J. (2011). Future sustainable supply chains: what should companies scan?. International Journal of Physical Distribution \& Logistics Management, 41(3), 228-252. https://doi.org/10.1108/09600031111123778

GARCIA N., PENTELSABELL FERANDEZ J., PRIORE P. (2013). Supplier selection model for commodities 
procurement. Optimised assessment using a fuzzy decision support system. Applied soft computing, 13, April 2013, 1939-1951. https://doi.org/10.1016/j.asoc.2012.12.008

HALLIKAS J., LINTUKANGAS K. (2016). Purchasing and Supply: An Investigation of Risk Management Performance. International Journal of Production Economics, 171(4), January 2016, 487-494. https://doi.org/10.1016/j.ijpe.2015.09.013

HUGHES J., Ertel D. (2016). THE REINVENTION OF PROCUREMENT. Supply Chain Management Review, 20(3), 18-23. https://www.logisticsmgmt.com/wp_content/vantage_wp_reinvention_procurement_062716.pdf

KEOUGH M. (1993). Buying your way to the top. The McKinsey Quarterly, (3), 41-62. https://link.galegroup.com/apps/doc/A14648444/AONE?u=googlescholar\&sid=AONE\&xid=aa32226e

LOPEZ S. M. (2016). Unclear corporate performance goals, metrics, and a lack of a future state definition in lean implementations failures: A study of the relationship. https://search.proquest.com/openview/5267f8e4d856319e8ea1d45385e1cdad/1?pq-origsite=gscholar\&cbl=1875 $0 \&$ diss $=\mathrm{y}$

PAIK, S.-K. (2011). Supply Management in Small and Medium-Sized Enterprises: Role of SME Size. Supply Chain Forum, an international Journal, 12(3), Management School Bordeaux. https://doi.org/10.1080/16258312.2011.11517269

ROZEMEIJER, F.A., VAN WEELE A.J., WEGGEMANN M. (2003). Creating Corporate advantage through purchasing: toward a contingency model. The Journal of Supply Chain Management, 39(4), 4-13. https://doi.org/10.1111/j.1745-493X.2003.tb00145.x

SÁNCHEZ-RODRÍGUEZ, C., MARTÍNEZ-LORENTE A. R., CLAVEL J.G., (2003). "Benchmarking in the purchasing function and its impact on purchasing and business performance". Benchmarking: An International Journal, 10(5), 457-471. https://doi.org/10.1108/14635770310495500

SCHIELE H. (2007). Supply-Management maturity, cost savings and purchasing absorptive capacity: Testing the procurement-performance link. Journal of Purchasing Supply Management, 13, 274-293. https://doi.org/10.1016/j.pursup.2007.10.002

SHARAAZ M. J. M. (2016). Strategy and profitability: Managing profits in inflation economy. Walden University and Scholar works. https://scholarworks.waldenu.edu/cgi/viewcontent.cgi?article=3863\&context=dissertations

TEAM FME (2013). free management e-books. http://www.free-management-ebooks.com/dldebk-pdf/fme-pestle-analysis.pdf

THOMPSON A. E. (2016). "Improved characterization and modeling of supply chain relationships". Dissertations and Master's Theses (Campus Access). Paper AAI10142882. https://digitalcommons.uri.edu/dissertations/AAI10142882

VAN POUCKE E. (2016). Climbing the stairs of purchasing maturity: Essays on purchasing development, internal service quality and sourcing outcomes. ProQuest Dissertations Publishing. https://search.proquest.com/docview/1829622384?accountid=59680 